\title{
Orthios as a Quality of Sound
}

\author{
Nina Almazova
}

St. Petersburg State University,

7-9, Universitetskaya nab., St. Petersburg, 199034, Russian Federation; n.almazova@spbu.ru

For citation: Nina Almazova. Orthios as a Quality of Sound. Philologia Classica 2020, 15 (1), 25-36. https://doi.org/10.21638/spbu20.2020.102

An attempt to interpret the famous ancient musical composition known as ó $\rho$ เoৎ vó $\mu$ oc requires an analysis of all available evidence connecting ő $\rho$ เo description of this nome (Dio 1. 1) ascribes it a military (or generally stimulating) character. This conforms with a number of passages, where an o' $\rho \theta$ เoc sound 'makes one stand up' to help, or to fight, i.e. it stimulates dynamic activity. Perhaps, then, this was the initial meaning of the adjective, from which it eventually morphed to mean 'sonorous' or 'piercing. It seems that a sound could be made piercing and pervasive both by its volume and by its pitch, therefore ô $\rho \theta ı \varsigma$ as a quality of sound frequently correlates with 'loud' and 'high'. Nevertheless, a common interpretation that equates ô $\rho$ เo in ancient Greek concerning a sound's pitch is ókús - ßapúc ('sharp' - 'heavy'), whereas the spatial metaphor of vertical ('high' - 'low') is not reliably attested. Another character-

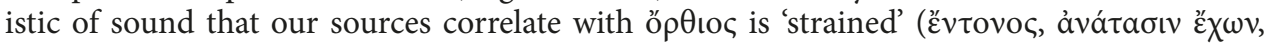

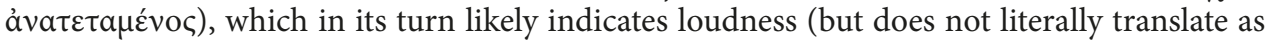
either 'high' or 'swift') and physical effort on behalf of the performers, or else the ethos of a musical piece, which transmitted tension to the audience.

Keywords: Ancient Greek music, nomes, orthios.

This paper continuous my reflections on the famous ancient musical composition

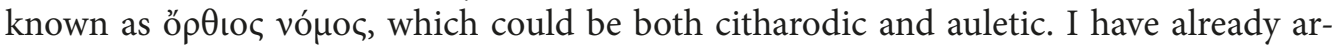
gued $^{1}$ that, in spite of what Pollux (4. 65), Hesychius (o 1188 Latte) and the Suida (o 575) claimed, this name was unlikely due to the piece's rhythm. Modern scholars who do not accept Pollux' explanation typically believe that ó $\rho \theta$ เoৎ was a characteristic of pitch. ${ }^{2}$ If true, then our understanding of the way in which pitch was indicated in ancient Greek must be called into question: the metaphor used for high pitch is generally agreed to be "sharp" (ỏúc) - not "high". Less numerous are those who link the name ob $\rho$ เo to the overall character of the nome, and even here high pitch may be thought to form one of its characteristic features. ${ }^{3}$

1 Almazova 2019.

2 Graf 1888, 512-523; Smyth 1904, 167; Salazar 1954, 278; 302; Del Grande 1960, 424; Pintacuda 1978, 43; id. 1982, 17 n. 1; Barker 1984, 252.

${ }^{3}$ Volkmann 1856, 70: corresponding in mood to Hom. Il. 11. 10-11; Crusius 1894, 52 n. 65: an elevated genre, 'hohe Liede' of Apollo; Weil-Reinach 1900, 105: "dans une tessiture claire, perçante, c'està-dire aiguë"; Wilamowitz-Moellendorff 1903, 90: "die laute Weise"; Olivieri-Pannain 1917, 122: "in una tessitura risonante, dignitosa, in un tono alto e solenne"; Schmidt-Stahlin 1929, 405 n. 7: "Plut. De Pyth. or.

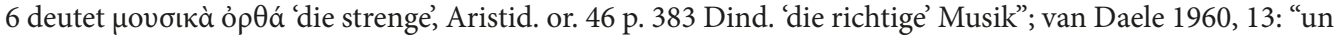
hymne guerrier"; 136 n. 3: "vif et entrainant". Gevaert 1881, 317 accepts all the variants at once: the nome of Terpander was named by rhythm, other orthian nomes by high pitch and elevated character.

(C) St. Petersburg State University, 2020 
Let us analyse the testimonies which connect the word of $\rho \theta$ เo with sounds. The most extensive description of the orthian nome is provided by Dio Chrysostomus (1. 1):

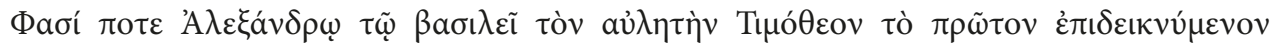

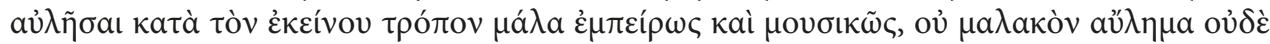

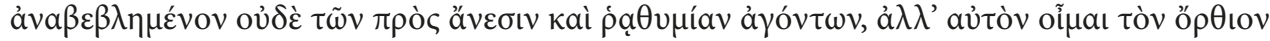

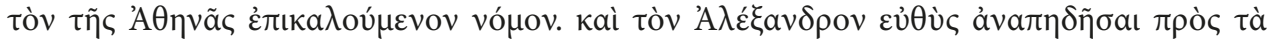

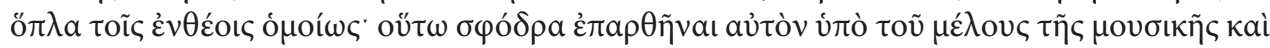

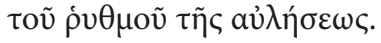

The story goes that when the aulos-player Timotheus gave his first exhibition before King Alexander, he showed great musical skill in adapting his playing to the king's character by selecting a piece that was not languishing or slow nor of the kind that would cause relaxation or listlessness, but rather, I fancy, the orthian nome which also bears Athena's name and none other. They say, too, that Alexander at once bounded to his feet and rushed for his arms like one possessed, such was the exhalation produced on him by the tones of the music and the rhythmic beat of the rendering. ${ }^{4}$

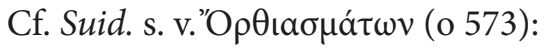

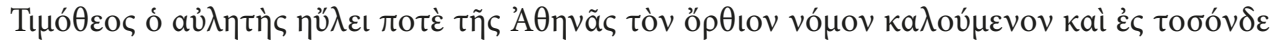

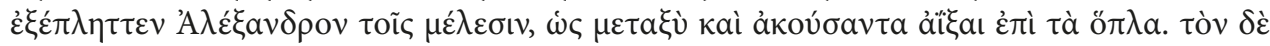

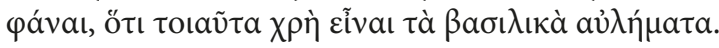

Timotheus the aulete once played on his aulos the nome of Athena named orthios and stroke Alexander so much with the music that in the middle of the performance he rushed for his arms. And Timotheus said that royal aulos-music ought to be such.

This anecdote is first attested in Plutarch (de Alex. fort. aut virt. 335A), yet through a slip of memory ${ }^{5}$ he gets his names mixed up, identifying the aulete Antigenides instead of Timotheus and the chariot nome instead of the orthian. Shorter versions of the same story occur several more times in Byzantine literature, ${ }^{6}$ and the interpretation of ó $\rho \theta$ เo as martial is attested in the scholia to Aeschylus. ${ }^{7}$ The episode must have formed part of a more elaborate story of how Timotheus was able to manipulate Alexander's mood with his art and used it for the benefit of the king, preventing him from running to extremes. ${ }^{8}$ It certainly arose in philosophic circles, which adhered to the doctrine of an ethical impact of music, and can hardly claim any historical credibility. However, it cannot be ruled out that the story was invented by an author from the fourth or the third century BC who could still listen to the nomes being performed and judge them from personal experience,

4 Translation: Cohoon 1971, 3 with minor changes.

5 See Almazova 2014, 524.

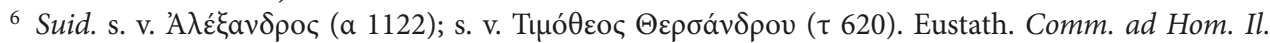

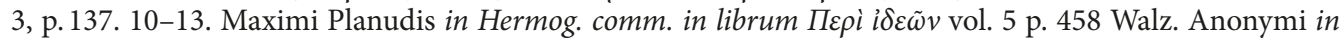

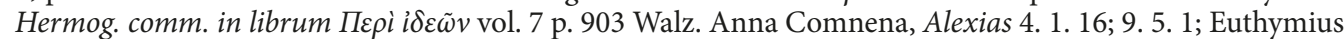
Tornices, Or. 1. 2; Michael Choniates, Or. 4. 24, vol. 1 p. 101 Lampros; Nicolaus Mesarites, Seditio Ioanni Comneni p. 34 Heisenberg.

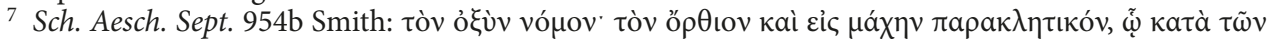

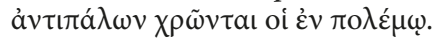

8 This story is recounted below by Dio himself (1. 6-7), and besides by Himerius (Orat. 16. 3 [p. 104. 12-19 Colonna]) and Sopater (Schol. ad Hermog. 5, p. 21. 19-21 Rabe = vol. 4 p. 50.28 Walz). Its source is unknown, see Wegehaupt 1896, 46; Brussich 1995, 150. 
and he specifically chose the orthian nome because of its military (or generally stimulating) character.

Unfortunately, the interpretation of this nome in the Imperial period could equally

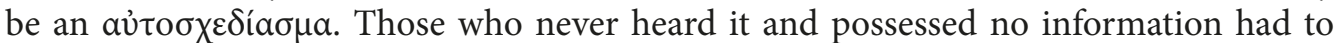
resort - just as we do now - to considering the name óp $\theta$ เoc, 'making stand up', to be suitable for an 'incentive' nome. Besides, the grammarians may have been influenced by the widely-known Homeric verse in which Eris inspires the Achaeans to courage with a loud cry (Il. 11. 10-11):

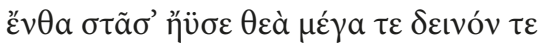

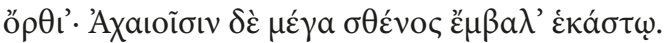

There stood the goddess and uttered a great and terrible shout, a shrill cry of war, and in the heart of each man of the Achaeans she put great strength...

The shout of the goddess produced the same effect on the warriors as Timotheus' nome on Alexander - hence perhaps an understanding of the orthian nome as calling for battle. ${ }^{10}$ Indeed, the scholia explain one case with the help of the other: the scholiast of Aristophanes references Homeric lines in his explanation of the orthian nome, while Eustathius cites the anecdote about Alexander when reviewing the cry of Eris in Homer. ${ }^{11}$

Late evidence on the orthian nome is inevitably conjectural: ancient commentators made the known meanings of o $\rho \theta$ toc their point of departure and tried to choose one which would fit references to the orthian nome in classical texts. ${ }^{12}$ There is nothing else left for us but follow their example and consider the attested occurrences of o $\rho \theta t o c$ in the acoustic sphere.

First of all, there are passages supporting the version that an ö $\rho \theta$ เo s sound "makes one stand up", i.e. stimulates dynamic activity. The earliest example of this is the passage from the Iliad cited above (Il. 11. 10-11). Scholiasts interpret ob $\rho \iota \iota$ as indicating loud-

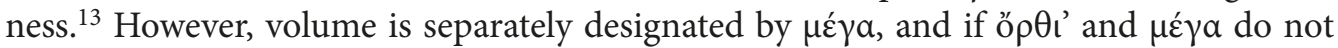
duplicate each other, it must follow that there was no implicit connotation of loudness in o $\rho \theta t o \varsigma-$ at least not in the language of early epic poetry. Whereas $\mu \varepsilon \varepsilon_{\gamma} \alpha$ and $\delta \varepsilon เ v o ́ v$ are used adverbially, the substantivated ö $\rho \theta \iota$ is rather an inner object: that is, a shrill cry

9 Translation: Murray 1924, 481.

${ }_{10}$ Volkmann 1856, 70; 116 actually derived the name of the nome from this Homeric passage; their relation was also stated by Weil-Reinach 1900, 35; Olivieri-Pannain 1917, 116.

${ }^{11}$ Sch. Aristoph. Ach. 16a (cf. Suid. s. v. ö $\rho$ өıv vó $9-15$.

12 Due to classical texts and subsequent commentaries, the expression ö $\rho \theta$ เoৎ vó $\mu \circ$ ৎ in Late Antiquity and in Byzance formed part of educated rhetoric. Some authors share Dio's idea that the orthian nome was an inspiration to battle (see n. 6 above), whereas for others it was simply an ancient classical piece of music. A song of Apollo's swans: Philostr. Maior, Imag. 1. 9. 4. A solemn, extensive and elaborate festive song (a metaphor for a rhetoric speech): Himer. Or. 4. 4, 38 (cf. Völker 2003, 323; 325); Nicetas Choniates, Or. 3 ,

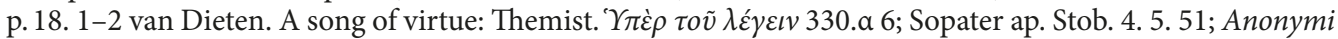
miscellanea philosophica 10, p. 27. 4 Pontikos; Georgius Tornices, Or. 1, p. 75. 10 Darrouzès; Manuel Gabalas, Epist. B 35, 1. 123 Reinsch; Gennadius Scholarius, Tractatus de processu spiritus sancti I, pars 2, p. 53.24 Jugie-Petit-Siderides. Nonnus rather mechanically applies ö $\rho \theta$ เoc to musical sounds as an epithetum

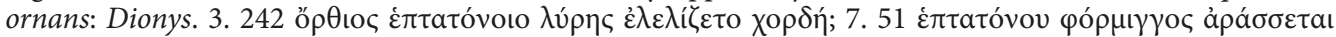

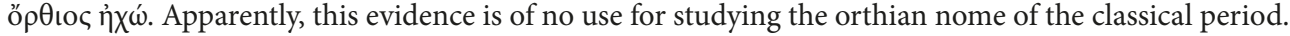

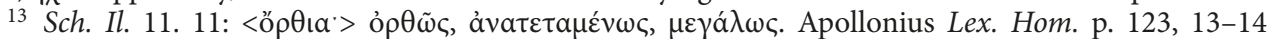

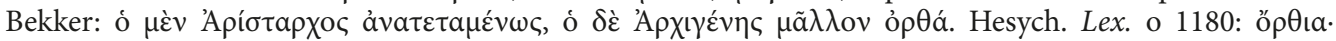

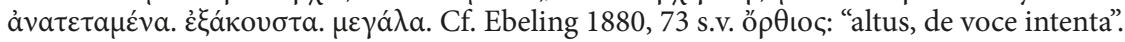


such as those which Homeric heroes often utter in a battle to inspire themselves and their companions. ${ }^{14}$ In fact it corresponds to a signal for combat. ${ }^{15}$

It seems that tò ô $\rho \theta ı v$ did have this technical meaning in the classical period. A signal for starting a battle played on a salpinx is twice mentioned by Euripides (Hera-

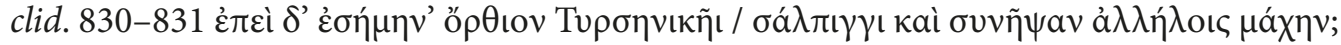

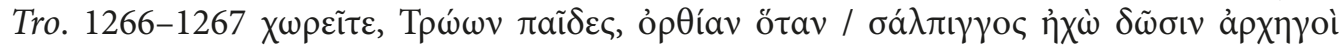

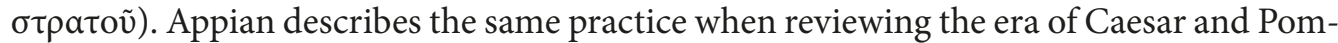

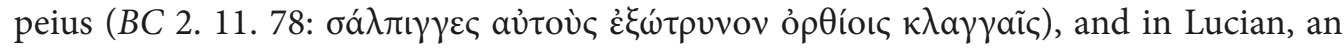
analogous signal of alarm is given with a horn by a satyr in a disturbed Dionysian troop

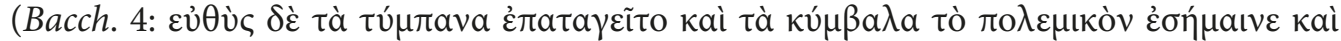

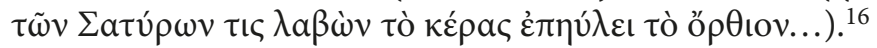

In the Homeric hymn to Demeter, ô $\rho \theta$ ı means the shout of Persephone in the mo-

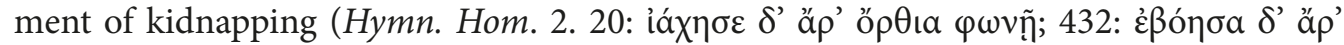
ó $\rho \imath \iota \alpha \varphi \omega v \tilde{n})$. The same epic expression is reproduced by Apollonius of Rhodes, as his her-

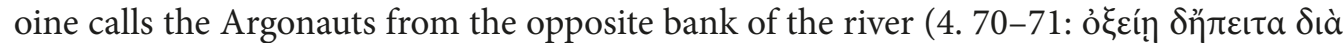

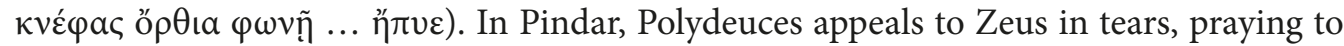
let him share his brother's fate (Nem. 10. 76: ö $\rho \theta$ ıov $\varphi \omega ́ v a \sigma \varepsilon)$. In Aeschylus (Cho. 732) the nurse recalls her hard labour and wittily names the baby's crying ö $\rho \theta \imath \alpha \varepsilon \lambda \varepsilon v ́ \mu \alpha \tau \alpha$. In the

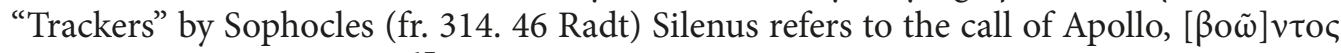

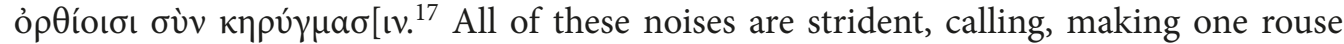
oneself, jump to one's feet, come to aid, succour.

Connecting this precise meaning of the adjective to the orthian nome is possible due to a pun in Aristophanes (Eccl.739-741): sounds that wake sleeping people at an ungodly hour - most probably the noise of a hand-mill ${ }^{18}$ - are called vó $\mu$ os ô $\rho \theta \rho$

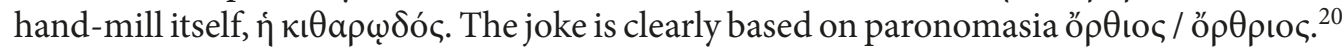
Admittedly the similarity of the word chosen to describe every-morning "music" to an actual musical term could in itself be amusing, never mind what the term actually meant. Still if the orthian nome was indeed similar to a reveille, the joke is much better. Thus, the

14 See Il. 5. 302, 591; 8. 159, 321; 11. 15, 344, 530; 12. 125, 252, 377, 439; 13. 149, 332, 540, 755, 834, 835,$837 ; 14.4,147-152,393-401,421 ; 15.312-313,321,353,355,384,506,590,658 ; 16.78-79,378,566$, 785; 17. 263-266, 723; 19. 41, 424; 20. 48-51, 285, 443.

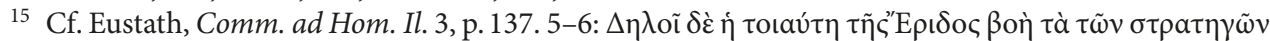

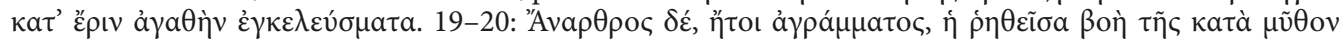
"Е

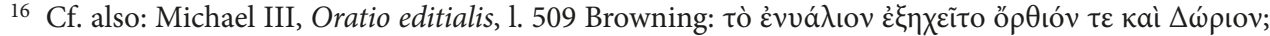

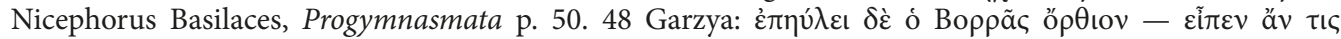

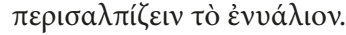

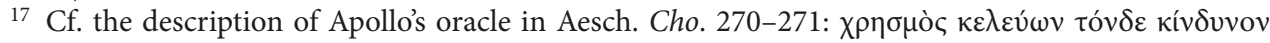

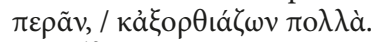

18 Meineke 1865, 201; Bachmann 1878, 16; Blaydes 1891, 171; Van Leeuwen 1905, 104; Huber 1974, 141-142. An allusion to a cock (Brunck 1783, Notae 42; Rogers 1902, 118-119; Ussher 1973, 179, 180) is impossible, since Aristophanes uses the feminine genus.

19 Grammarians ascribed not only a semantic, but also an etymological relationship to ö $\rho \theta \rho \circ \varsigma$ and ó $\rho \theta$ เoৎ (applied to getting up from the bed). (H)eren(n)ius Philo, De diversis verborum significationibus o

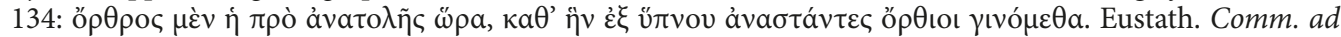

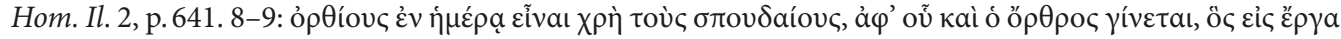

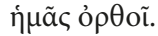

20 Blaydes 1891, 171, 172; Ussher 1973, 180. 


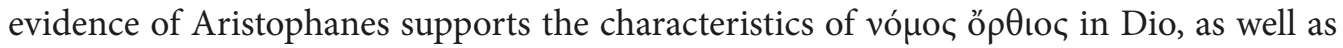
the presumption that the auletic and the citharodic orthian nome shared the same quality.

Stretching from the concept of 'making stand up' to 'stimulating' when considering a sound is, of course, only a hypothesis. ${ }^{21}$ Yet we can take for granted that, whatever the 'stretch' was, in the end of $\rho$ to amples at our disposal are not restricted to emergency situations, be it calling for aid, or a fight. In particular, the epithet ó $\rho \theta$ เo s suits public announcements meant to attract gener-

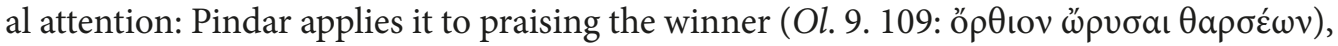

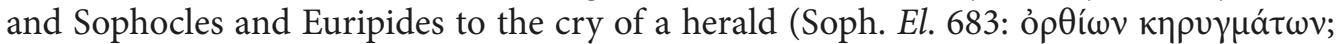

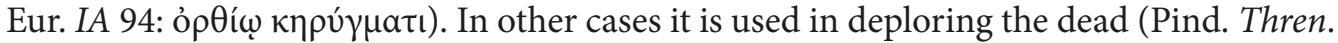
fr. 128e a2: ö] $\rho \theta$ เov lá $\lambda \varepsilon \mu$ [ov; Soph. Ant. 1206: ỏ $\rho \theta i ́ \omega v \kappa \omega \kappa v \mu \alpha ́ \tau \omega v) .{ }^{23}$

It is clear that a sound can be made piercing and pervasive both through its intensity, and through its pitch. Remarkably, scholiasts and lexicographers mention tension, loudness and high pitch in describing the same sounds: ${ }^{24}$ apparently these features often combine. Therefore, in almost all the cases considered above the meaning 'loud' could also be postulated for ö $\rho$ เ

Frequent correlation of this characteristic with high pitch is also understandable. Still a widespread interpretation simply equating ö $\rho \theta เ \varsigma$ to ỏ $\xi u ́ \varsigma^{25}$ is unwary. As is generally known, conventional metaphor applied to sound pitch in ancient Greek is ỏ zúc - $\beta a \rho u ́ c$ (literally 'sharp' - 'heavy'), ${ }^{26}$ and not 'high' - 'low'. To adduce one manifest proof, the

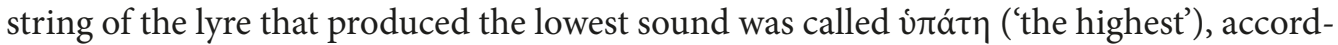

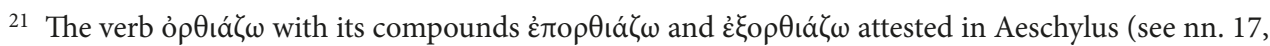

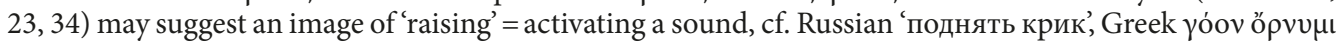
(Od. 17. 46). Crusius 1894, 52 n. 65 considered the name 'orthian nome' to be derived from this verb.

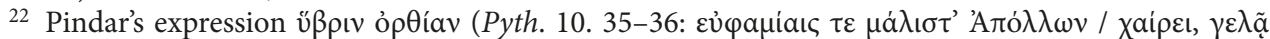
$\theta^{\prime}$ ó $\rho \tilde{\omega} v v \ddot{\beta} \beta \rho \iota v$ ỏ $\left.\rho \theta i a v \kappa v \omega \delta \dot{\lambda} \lambda \omega v\right)$ might possibly mean cries of donkeys (Graf 1888, 513), but it is safer to exclude it from consideration, since this sense is not certain: Crusius 1894, 52 justly observes that o $\rho \tilde{\omega} v$ could hardly be said of sounds. For an alternative (most probably correct) interpretation see Sch. Pind. Pyth. 10. 55-56; Bernardini 1991, 155-159; Montanari 2004, s. v. ő $\theta$ เo ("lubricità degli animali che si erge"). The claim that o $\rho \theta i a v$ is a metrical term here (Zielinski 1883, 626-627) is completely unfounded (Graf 1888, 513; Crusius 1894, 52).

${ }^{23}$ Cf. the related verbs in Aeschylus: Pers. 687 ỏ $\rho \theta$ เá

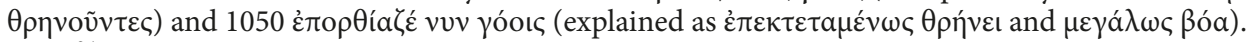

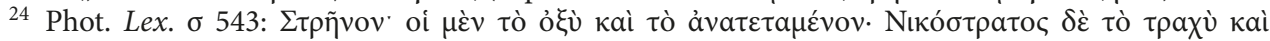

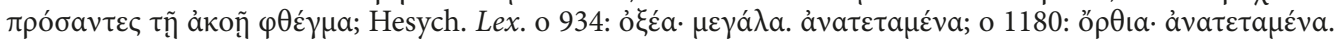

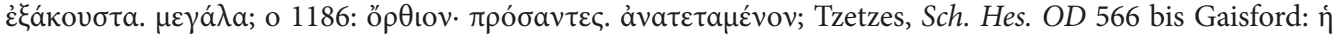

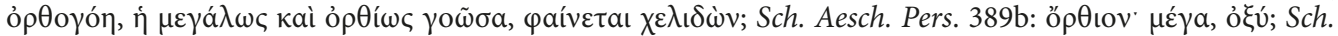

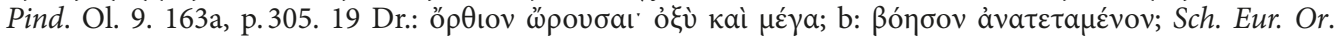

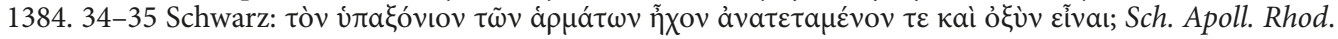

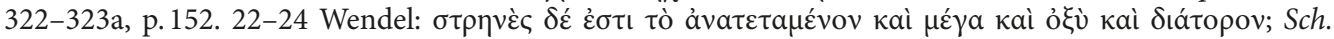

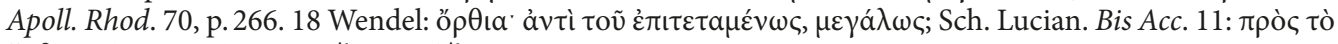

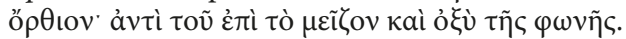

25 Smyth 1904, 167; Lasserre 1953, 23; Del Grande 1960, 424; Pintacuda 1978, 43; Barker 1984, 251; 252.

26 Figurative meaning of these definitions in music was not left unnoticed by Aristotle, De anima

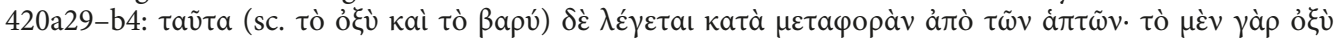

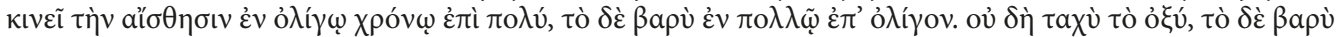

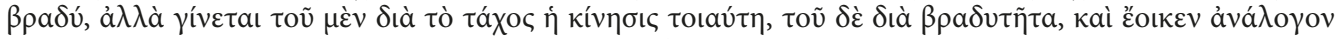

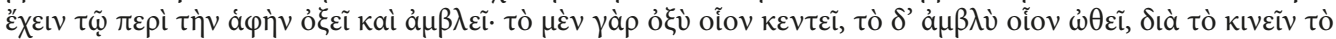

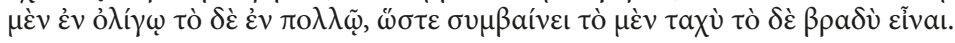


ing to its location while playing the instrument. So, the meaning 'high-pitched' is not natural for ö $\rho \theta$ toc.

Its supporters refer to Ps.-Aristot. Probl. 19. 37, 920b18-21:27

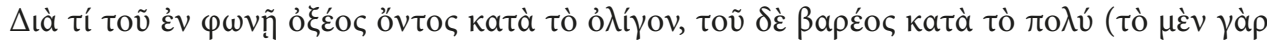

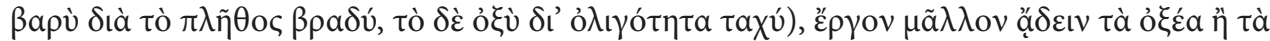

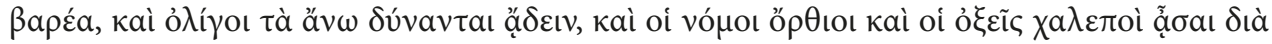

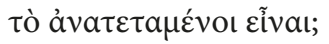

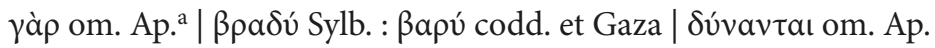

Why is it, given that high pitch in sound goes with smallness and low pitch with large quantity (since what is low-pitched is slow because of the quantity, while what is high-pitched is swift because of the smallness), that it is harder work to sing high pitches than low ones, and few people can sing the upper notes, and the Orthioi and Oxeis nomoi are difficult to sing because they are tightly stretched?28

However, the fact that the author found it necessary to use both words, ö $\rho \theta$ เoเ kaì ỏ $\xi \varepsilon \tilde{c}$, , implies their semantic difference. ${ }^{29}$ Perhaps it consists in ö $\rho \theta$ เo c combining the notions of high pitch, loudness and tension. Besides, it has been noticed that tà ố $v \omega$ in this passage is applied to upper notes. ${ }^{30}$ Yet H. Bonitz proposed a convincing explanation: by enumerating in succession tà ăv $v$ means items named at the beginning of the sequence, ${ }^{31}$ and the degrees of a scale were conventionally enumerated downwards. ${ }^{32}$ Thus the spatial metaphor of vertical used for pitch is not reliably attested in Greek and cannot be mechanically applied to defining ö $\rho \theta เ$ เo .

In the examples considered above the shouting of a girl and the crying of a baby are obviously high-pitched sounds. This meaning (though alongside with 'loud' and 'piercing') also suits the passage Aesch. Ag. 1153, where ecstatic outcries of Cassandra foreseeing her own death are metaphorically called ö $\rho \theta เ o$ vó $\mu_{0}{ }^{33}$ - not only because a woman's part is concerned, but also because high pitch was typical of lamentation. ${ }^{34}$

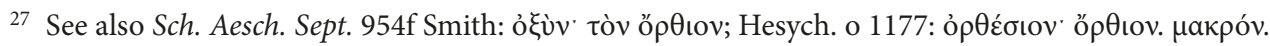
ỏ $\xi \dot{v} . \mu \varepsilon \dot{\gamma} \gamma$.

28 Transl. Barker 1989, 94.

29 Marenghi 1957, 110: "dal presente problema si può desumere similarità tra i due, non assoluta

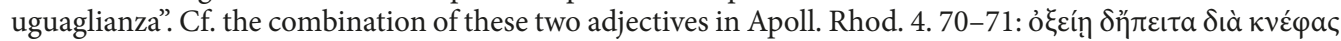
ö $\rho \iota \alpha \varphi \omega v \tilde{n} \ldots$..

30 Exclusively on the base of this passage, Graf 1888, 514 claimed: "die Griechen hatten $\langle\ldots>$ dieselbe räumliche Vorstellung von der Tonreihe wie wir", and Gevaert 1899, 100 with n. 2 even proposed an explanation of this common notion: while singing, high sounds allegedly seem to resound in the head, and low sounds in the thorax.

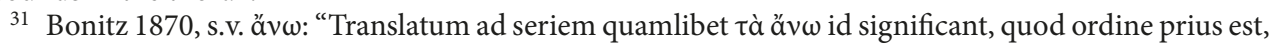

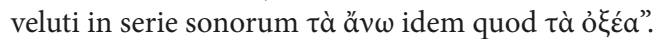

32 See e.g. Ps.-Aristot. Probl. 19. 33. In vocal notation alpha signifies the upper and omega the lower sound; the degree of the scale named $\tau$ íi $\eta$ is the third from above: Gevaert 1899, 174.

33 Graf 1888, 513; Smyth 1904, lxiii; Pintacuda 1978, 113.

34 See Plat. Resp. 398e; Sch. Eur. Or. 176, p.116. 16-17 Schwartz; Ps.-Plut. De mus. 1136C; cf. oi

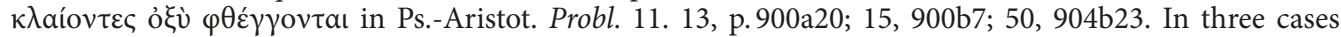
adduced above ö $\rho \theta$ เo is a characteristics of weeping: Pind. Nem. 10. 76; fr. 128e a2; Soph. Ant. 1206. Yet it should be noted that mournful character cannot be considered typical of ö $\rho \theta เ o \varsigma$, as examples clearly show (festive context: Sappho fr. 44. 32 Voigt; Pind. Ol. 9. 109; cf. the related verb: Aesch. Ag. 28-29 ỏ $\lambda$ o $\lambda v \gamma \mu$ òv ...

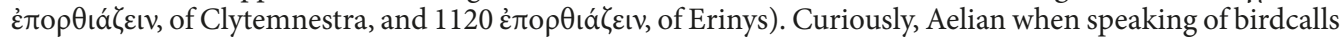


On the other hand, a herald or Apollo was hardly likely to be shrieking in tragedy. Sappho (fr. 44. 31-34 Voigt) also uses ö $\rho \theta$ เo when recalling a shout of men (apparently the ritual exclamation 'ie paean ${ }^{35}$ ) at the wedding of Hector and Andromache:

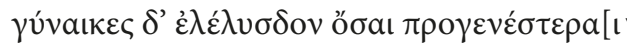

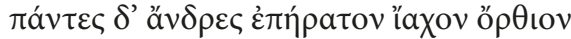

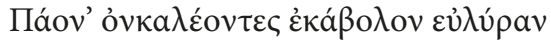

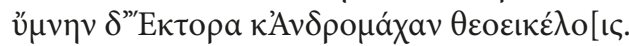

The elder women cried out joyfully, and all the men let forth a lovely ö $\rho$ өıv strain calling on Paean, the Archer skilled in the lyre, and they sang in praise of the god-like Hector and Andromache. ${ }^{36}$

Given that the exultant shout of men rings alongside that of women, ö $\rho \theta$ เov presumably implies loud volume, since it could be only relatively high-pitched (as well as a citharodic nome performed by a male singer). Actually, some parallels show that even a cry of men - namely of warriors - could be thought of as high, for the adjective ỏ $v^{\prime} \varsigma$ characterizes it. Yet perhaps only one kind of cry - $\dot{a} \lambda \alpha \lambda \eta$ - is implied. ${ }^{37}$ "O $\rho \theta$ เov is applied to an echo of such an ả $\lambda \alpha \lambda$ ń of the Greek sailors in Aesch. Pers. 389-391 (óp $\theta$ เov $\delta$ '

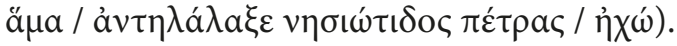

Therefore, I am inclined to believe that the sounds which could be called ob $\rho \theta$ เo were frequently but not necessarily high-pitched.

While explaining the orthian nome, several times scholia to Aristophanes use words with the stem ten-/ton-/tan- which in their turn need interpretation: ${ }^{38}$

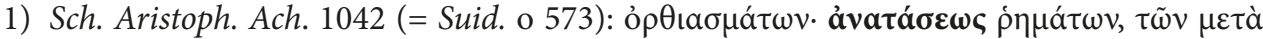

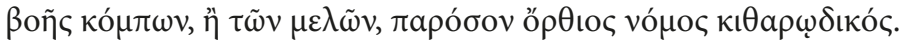

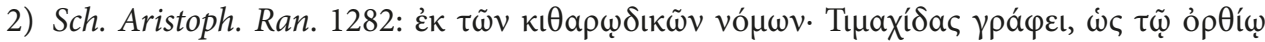

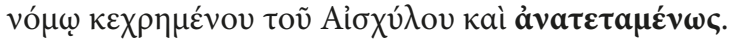

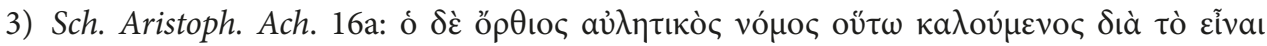

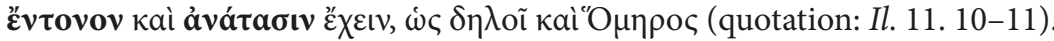

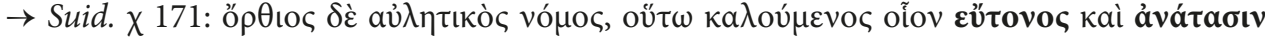

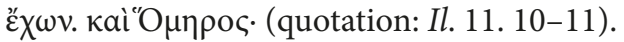

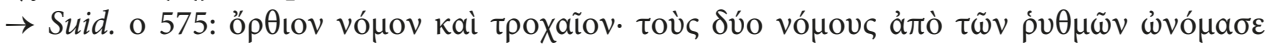

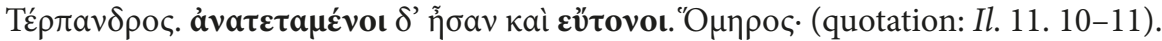

(NA 6. 19) opposes ö $\rho$ เ $а$ to mournful and 'womanly' (i.e. high?) sounds, but unites them with piercing

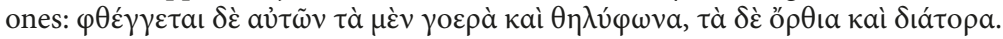

35 Rutherford 2001, 56 translates: "All the men sang the lovely high-pitched paean". Yet the lines 3233 suit better a paean-cry than a paean-song: it is the cry that could sound without prejudice together with the women's shout, while the song following it is first mentioned in line 34. The epithet $\dot{\varepsilon} \pi n$ patov does not contradict to this understanding: it can characterize the cry as harmonious and as prophesying fortune. ú $\mu \nu \eta v$ is interpreted as impf. 3 pl. (Hamm 1958, 163) or as inf. epexegeticus governed by la 73 n. $1 ; 368)$.

36 Trans. Campbell 1990, 91.

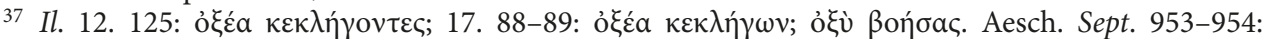

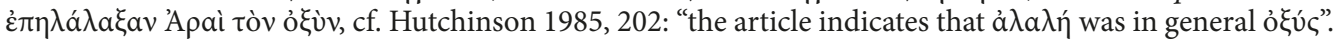

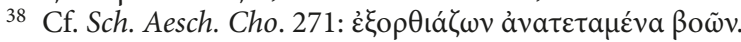




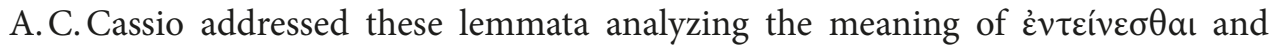

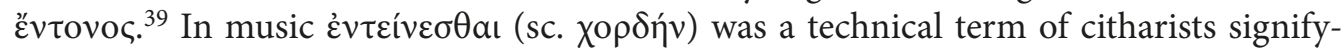
ing 'to strain (a string)' and therefore 'tune up' (Ps.-Aristot. Probl. 19. 42, 921b26; Aristox. Elem. harm. p. 53. 9 Da Rios=43, 30 Meibom; Lucian. Dial. deorum 11. 4). Despite

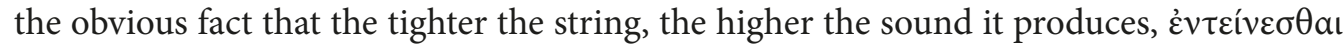
taken alone does not imply an upper register, as is shown by Cassio (pace LSJ s.v.: 'pitching high'). Besides it develops the figurative meaning 'strain' (extended in particular from the

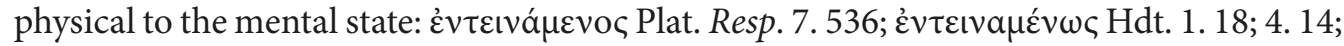

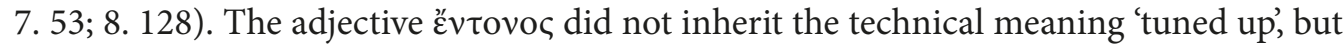
means 'vigorous, intensive, strained, violent' (see Hdt. 4. 11; Soph. fr. 842 Radt; Eur. Or. 698; Hipp. 118; fr. 291. 1 Kannicht $=\mathrm{N}^{2}$ ).

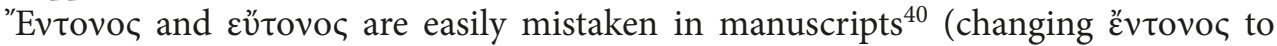

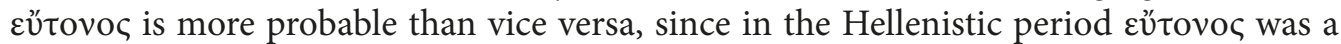
common word, while है $v$ tovo became more and more rare ${ }^{41}$ ). According to the analysis of

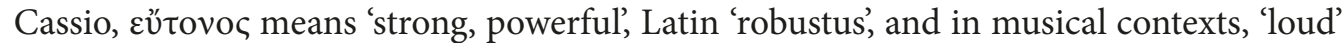
(Arist. Quint. 1. 21, p. 43. 13; cf. 42. 26-27 W.-I.). ${ }^{42}$

In the scholium to Ach. 16, as well as in both lemmata of the Suida quoting this scholium, Cassio proposed reading forms of हैvтovos 'strained', and referred to the passage of Dio (Or. 1. 1) describing the orthian nome as oủ $\mu \alpha \lambda \alpha \kappa o ̀ v$ aủ $\lambda \eta \mu \alpha \ldots$ oủ $\delta \dot{\varepsilon} \tau \tilde{\omega} v$

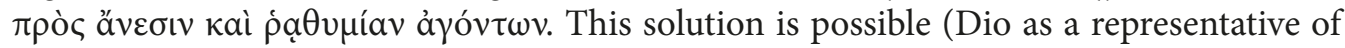
ancient book culture is likely to express the same opinion as the scholiasts). Yet further considerations of Cassio are inconclusive: he negates the connotation of loudness for the

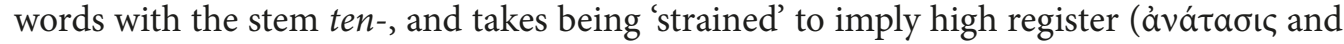

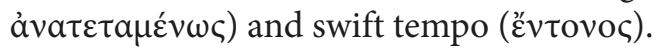

To begin with, it is unconvincing that a nome pitched high, which is difficult to sing

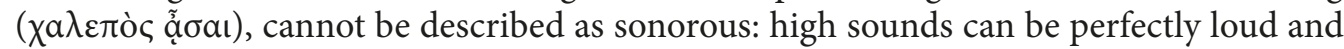
penetrating, which is proved by a series of cases using ő $\rho \theta \iota \varsigma$, as well as a direct indi-

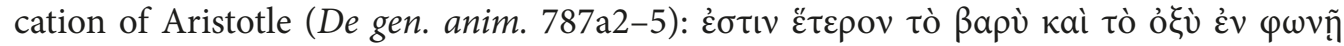

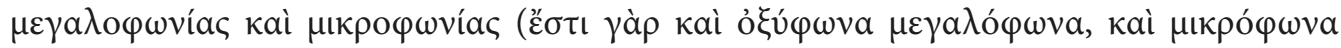

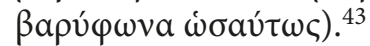

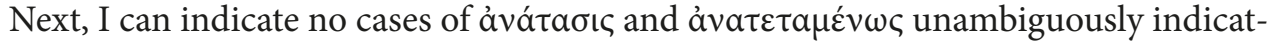

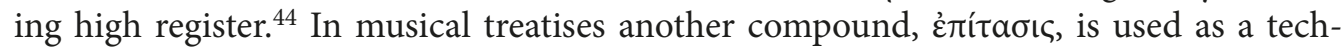
nical term for increasing pitch (e.g. Cleonid. Isag. harm. 2, p.181. 1-6 Jan). Cassio, to prove his understanding, cites the passage adduced above, Ps.-Aristot. Probl. 19. 37: kaì oi vó order to avoid the tautology ("high nomes are difficult to sing because they are high")

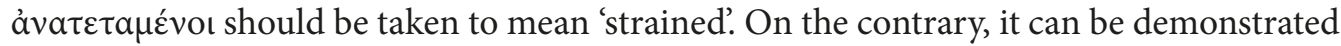
that these words are related to loudness, which is a natural result of tension: it is not an

39 Cassio 1971.

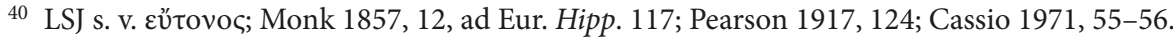

41 Cassio 1971, 56 n. 2.

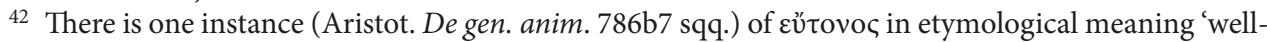
pitched', remarkably applied to the middle register - neither too high nor too low (on animals' voices).

43 See also an observation of Theophrastus (ap. Porph. in Ptol. Harm. p. 63. 1-6 Düring) that singers spend great forces both when singing high and low.

${ }^{44}$ In several cases tension combines with high pitch (see above n. 24). 


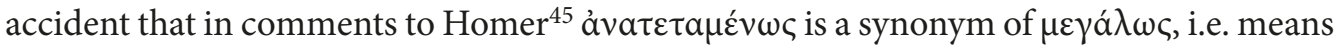
'loudly'. ${ }^{4}$

As regards évนovos, there are no convincing examples showing that it can mean 'in a swift tempo'. Cassio refers to Soph. fr. 966 Radt and Aristoph. Ach. 674, but in both cases, firstly, the reading is not certain, and secondly, the context allows not only the meaning 'swift' but also 'loud' and 'intense'. We seem to have no grounds at all to think that ع́v was ever used as a musical term. ${ }^{47}$

That the Greeks felt a tie between high pitch and swift tempo is by no means obvious. Numerous evidence on correlation of pitch and speed (including Probl. 19. 37) has nothing to do with the duration of sound itself and consequently with the tempo. It concerns the most popular ancient acoustic theory, which suggested that a high sound was a result of swift movement of air, and a low sound, a result of slow movement. ${ }^{48}$

Probl. 19. 21, 919a29-35 seems to stand apart at first glance: it is argued that mistakes are more evident in singing low, because the listeners have more time to notice them.

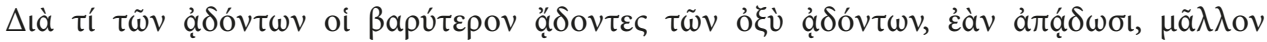

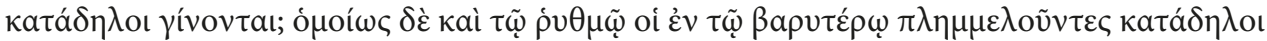

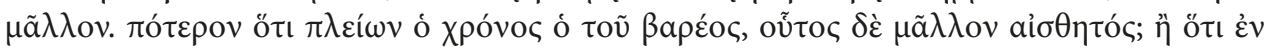

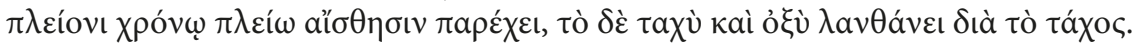

Why is it that when people are singing, those who sing lower pitches, if they sing wrongly, do so more detectably than those who sing high? In rhythm, similarly, those who make mistakes in a slower rhythm do so more obviously. Is it because the time taken by something low-pitched is longer, and it is therefore more perceptible, since in the longer time it generates more sensation, while what is swift and high-pitched escapes detection because of its swiftness ${ }^{49}$

However, since it is undeniable that high and low sounds can last equally long, ${ }^{50}$ this passage most likely does not concern the tempo, but the nature of sound. ${ }^{51}$ The author apparently shares the theory that every sound is discreet, that is, consists of a series of quick impacts separated by short spaces of silence, which blend with each other in our perception. ${ }^{52}$ A high sound is produced by more impacts in a certain period of time than a low

45 See above n. 13.

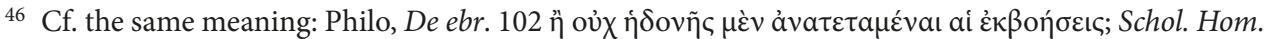

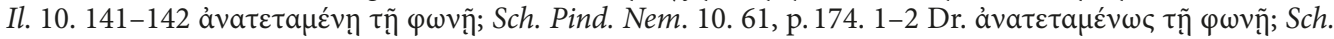

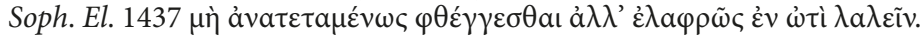

47 Cassio is aware $(1971,56)$ that $\varepsilon^{\prime} v \tau o v o \varsigma$ in Aristides Quintilianus occurs only once, in a medical simile (2. 16, p. 85. 29 W.-I.).

48 Archytas fr. 1 Diels-Kranz (Porphyr. In Ptol. Harm. p. 57 Düring=p. 196-198 Barker); Plat. Tim. 67b5-6; 80a3; Aristot. De anima 2. 8, 420a30-33; De gen anim. 5. 2, 786b25-787a28; Top. 107a15; Ps.Aristot. De audib. 803a5-6; Probl. 11. 3, 6, 10, 13, 14, 15, 16, 34, 47, 53, 56, 61, 62; Theo Smyrn. Expositio rerum math. p. 50. 11-12 Hiller.

49 Transl. Barker 1989, 92.

50 Gevaert 1899, 210, who thought the Problems to be the authentic work of Aristotle and refused to ascribe such blatant ignorance to the Stagirite, even suspected that the problem was a false one: the master aimed to provoke his students to take a critical approach to a generally accepted, but erroneous statement. Louis 1993, 98 supposed Byzantian interpolations in section 19 of the Problems.

51 Barker 1989, 92 n. 48.

52 Ps.-Aristot. De audib. 803b34-804a8; Probl. 19. 39; Porph. In Ptol. Harm. p. 31. 6-21 Düring. 
one. ${ }^{53}$ The author implies that the organ of hearing thus has less time for perceiving every impact formatting a higher sound than for perceiving impacts creating the lower one, so one's perception of the high register is less clear.

Thus, in the scholia to Aristophanes considered here I can see no indications of either high pitch or swift tempo for the orthian nome. Rather, it is characterized as intense and perhaps loud.

What 'tension' in music means is in its turn subject to interpretation. First, the scholiasts could imply physical effort required for producing sound. An eloquent description of a philosophical dispute in Lucian (Bis acc. 11) shows what strain tò ö $\rho \theta ı v$ demanded: ${ }^{54}$

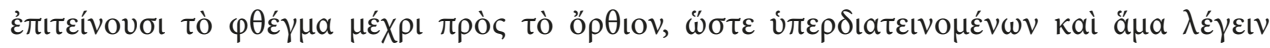

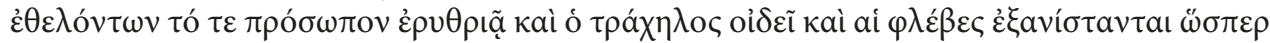

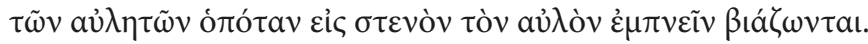

They raise their voices to a high falsetto, so that, with their excessive straining and their endeavour to talk at the same time, their faces get red, their necks get swollen, and their veins stand out like those of aulos-players when they try to blow into a close pipe. ${ }^{55}$

An evident consequence of such tension was the loudness. On the other hand, peripatetic evidence claims that singing high required more effort ${ }^{56}$ - presumably for a

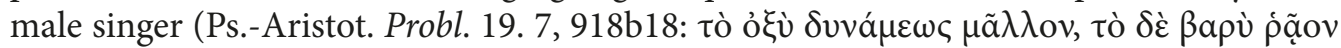

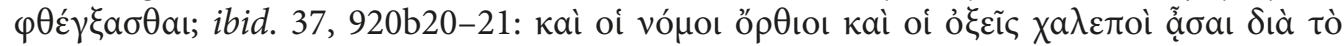

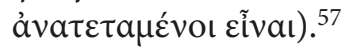

Second, the ethos of a musical piece could be implied, which in turn transmitted tension to the audience. In this case the question arises of what means might be used to give the impression of tension in music, but here we enter the sphere of guesswork. Maybe such an effect might be produced by sonority, as well as high pitch, for there is peripatetic evidence that it was perceived to be unstable: it was felt that a high register was not suitable for the ending of a musical piece; rather, a downwards procession was

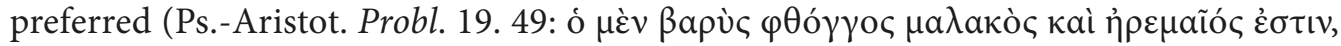

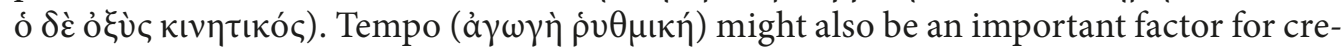
ating an ethos: ${ }^{58}$ Aristides Quintilianus claims that a swift tempo creates an energetic, vigorous ethos stimulating dynamic activity - exactly the mood ascribed to the orthian

${ }^{53}$ E. g. in a consonant of fourth the higher string makes four impacts to the lower's three. This theory need not imply that the pitch depends on the frequency of oscillation, and it does not contradict the former idea of the nature of pitch. It simply assumes that more numerous impacts are caused by quicker movement of a string: De audib. 804a2-4, see. Barker 1989, 95 n. 64; 107-108 n. 40.

${ }^{54}$ Cf. Plut. Phoc. 2: too harsh a course, opposed to everything the people desire, in administrating a

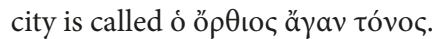

55 Translation: Harmon 1969, 103-105, with minor changes.

56 At the same time it was noted (e.g. Marenghi 1957, 103; Louis 1993, 98 - as a proof of a late

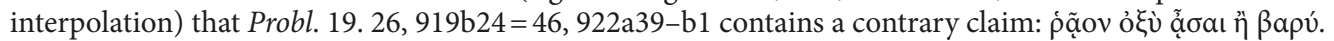

57 See above n. 24. Already Graf 1888, 513 concluded that ő $\rho$ เo combines the meaning 'high' and 'loud', since both aspects require the tension of the voice.

${ }^{58}$ Cassio 1971, 57. 
nome by our sources. ${ }^{59}$ The gradual increasing of several parameters such as volume and tempo might also help. ${ }^{60}$

I conclude that ô $\rho \theta ı$ เ as a characteristic of sound means 'attracting attention', 'penetrative', 'exciting'. It seems plausible that an orthian nome might be notable for its piercing sounding and tension, which could be achieved due to loudness, high pitch, and perhaps speed.

\section{Bibliography}

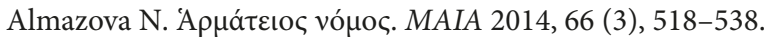

Almazova N. The Boeotian Nome. Philologia Classica 2015, 10, 7-30. (In Russian)

Almazova N. Orthios as a Rhythmical Term. Philologia Classica 2019, 14 (2), 164-176.

Bachmann O. Coniecturarum observationumque Aristophanearum specimen. I. Gottingae, officina Hoferiana, 1878.

Barker A.Greek Musical Writings. I. The Musician and his Art. Cambridge, Cambridge University Press, 1984.

Barker A.Greek Musical Writings. II. Harmonic and Acoustic Theory. Cambridge, Cambridge University Press, 1989.

Bernardini P. La hybris degli asini e il riso di Apollo in Pindaro, Pyth. 10, 36, in: Studi di filologia classica in onore di G. Monaco. I. Palermo, Università di Palermo, 1991, 155-159.

Blaydes F.H.M. (ed.) Aristophanis Comoediae. Pars III. Ecclesiazusae. Halis Saxonum, In orphanotrophei libraria, 1891.

Bonitz H. Index Aristotelicus. Berolini, Reimer, 1870.

Brunck R. F. Ph. (ed.) Aristophanis comoediae ex optimis exemplaribus emendatae. T. II. Sine loco, 1783.

Brussich G. F. Un auleta del IV sec. a.C.: Timoteo di Tebe, in: B. Gentili, F. Perusino (eds) Mousike: metrica ritmica e musica greca in memoria di Giovanni Comotti. Studi di metrica classica 11. Pisa, Rome, Instituti Editoriali e Poligrafici Internazionali, 1995.

Campbell D. A. (ed., tr.) Greek Lyric. I. Sappho and Alcaeus. Cambridge, Ma., Harvard University Press, 1990.

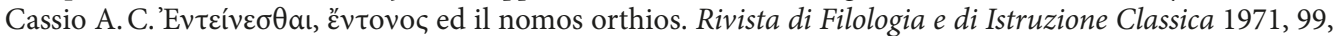
53-57.

Cohoon J.W. (ed., tr.), Dio Chrysostom. Vol. I.London, Heinemann; Cambridge, Ma., Harward University Press, 1971.

Crusius O. Die Delphischen Hymnen. Untersuchungen über Texte und Melodien. Göttingen, Dieterich, 1894.

Ebeling H. Lexicon Homericum. Lipsiae, Teubner, 1880, Nachdr. Hildesheim, Olms, 1987.

Gevaert F.A. Histoire et théorie de la musique de l'antiquité. II. Gand, Annoot - Braeckmann, $1881=$ Hildesheim, Olms, ${ }^{5} 1965$.

Gevaert F. A.; Vollgraff, J. C. Les probèlmes mousicaux d'Aristote. Gand, A. Hoste, 1899.

Del Grande C. La metrica greca, in: C. del Grande (ed). Enciclopedia Classica. Sez. II, vol. V, t. 2. Torino, Società editrice nazionale, 1960, 401-476.

Graf E. Nomos orthios. RhM 1888, 43, 512-523.

Hamm E. M. Grammatik zu Sappho und Alkaios. Berlin, Akademie-Verlag, ${ }^{2} 1958$.

Huber J. Zur Erklärung und Deutung von Aristophanes' Ekklesiazusen. Heidelberg, Diss., 1974.

Hutchinson G. O. (ed.) Aeschylus. Septem contra Thebas. Oxford, Oxford Clarendon Press, 1985.

Lasserre F. (ed.) Plutarque. De la musique. Texte traduction commentaire précécés d'uneétude sur léducation musicale dans la Grèce antique. Olten, Lausanne, Urs Graf, 1954.

Louis P. (ét., tr.), Aristote. Problèmes. II. Paris, Les Belles Lettres, 1993.

Marenghi G. (a cura di) Aristotele. Problemi musicali. Firenze, Sansoni, 1957.

Meineke A. Vindiciarum Aristophanearum liber. Lipsiae, Tauchniz, 1865.

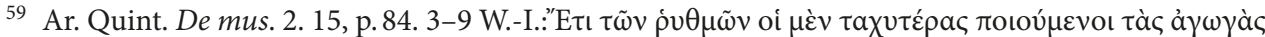

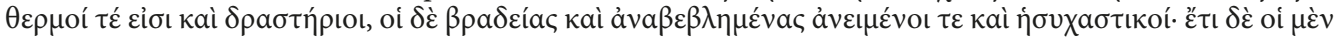

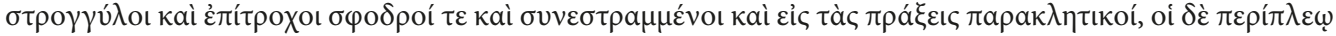

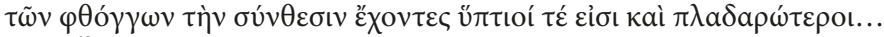

${ }^{60}$ I owe this guess to Dr. M.N. Kazanskaya. However, this seems to be a peculiarity of another nome, called Boeotian, see Almazova 2015, 15-16; 24. 
Monk J.H. Euripidis Fabulae Quatuor: scilicet Hippolytus Coronifer; Alcestis; Iphigenia in Aulide; Iphigenia in Tauris. Cantabrigiae, Deighton, Bell et soc., ${ }^{9} 1857$.

Montanari F. Vocabolo della lingua greca. Torino, Loescher, ${ }^{2} 2004$.

Murray A. T. (tr.) Homer, The Iliad. Vol. I. London, Heinemann; Cambridge, Ma., Harvard University Press, 1924.

Olivieri A.; Pannain, G. Nomos auletico. Memorie della Reale Accademia dell'Archeologia, Lettere e Belle Arti di Napoli 1917, 5, 97-122.

Pearson A. C. The Fragments of Sophocles, edited with additional notes from the papers of Sir R. C. Jebb and Dr. W. G. Headlam. III. Cambridge, Cambridge University Press, 1917.

Pintacuda M. La musica nella tragedia greca. Cefalu, Misuraca, 1978.

Pintacuda M. Interpretazioni musicali sul teatro di Aristofane. Palermo, Palumbo, 1982.

Rogers B. B. The Ecclesiazusae of Aristophanes Acted at Athens in the Year B. C. 393. London, Bell, 1902.

Rutherford I. Pindar's Paeans. A Reading of the Fragments with a Survey of the Genre. Oxford, Clarendon Press, 2001.

Salazar A. La musica en la cultura griega. Mexico, El colegio de México, 1954.

Schmidt W., Stahlin O. Geschichte der griechischen Literatur. 1. Teil, 1. Bd. (W. Schmidt). München, Beck, 1929.

Smyth H. W. Greek Melic Poets. London, Macmillan, 1904, repr. New York, Bibli \& Tannen, 1963.

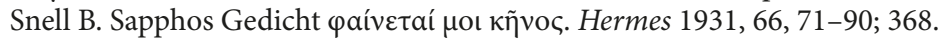

Ussher R. G. (ed.) Aristophanes. Ecclesiazusae. Oxford, Clarendon Press, 1973.

Van Daele H. (tr.) Aristophane. Vol. I: Les Acharniens - Les cavaliers - Les nuées. Texte établi par V. Coulon. Paris, Les Belles Lettres, 1960.

Van Leeuwen J. Aristophanis Ecclesiazusae cum prolegomenis et commentaries. Lugduni Batavorum, Sijthoff, 1905.

Völker H. (Einführung, Übers., Komm.) Himerios. Reden und Fragmente. Wiesbaden, Reichert, 2003.

Volkmann R. (ed.) Plutarchi De musica. Leipzig, Teubner, 1856.

Wegehaupt I. De Dione Chrysostomo Xenophontis sectatore. Gothae, Perthes, 1896.

Weil H.; Reinach Th. (eds.) Plutarque. De la Musique. Édition critique et explicative. Paris, Leroux, 1900.

Wilamowitz-Moellendorff U.von. Tinotheos. Die Perser. Leipzig, Hinrichs, 1903.

Zielinski Th. Apollon bei den Hyperboreern (zu Pind. Pyth. X). RhM 1883, 38, 625-627 .

Received: December 11, 2019

Accepted: March 10, 2020 